\title{
SOCIAL RETURN ON INVESTMENT (SROI) PROGRAM "SENTRA INDUSTRI BUKIT ASAM" (SIBA) BATIK KUJUR VILLAGE TANJUNG ENIM
}

\author{
Meilanny Budiarti Santoso ${ }^{1}$, Santoso Tri Raharjo ${ }^{2}$, Sahadi Humaedi ${ }^{3}$, Hendri Mulyono ${ }^{4}$ \\ ${ }^{1,2,3}$ Pusat Studi CSR, Kewirausahaan Sosial, dan Pengembangan Masyarakat UNPAD, Indonesia \\ ${ }^{4}$ Corporate Social Responsibility PT. Bukit Asam, Tbk., Indonesia \\ E-mail : meilanny.budiarti@unpad.ac.id', santoso.tri.raharjo@unpad.ac.id², \\ sahadi.humaedi@unpad.ac.id ${ }^{3}$,hendrim@bukitasam.co.id ${ }^{4}$
}

\begin{abstract}
The Corporate Social Responsibility (CSR) activities carried out by companies should ideally be a social investment for them. The activities should not necessarily be aimed to meet their responsibilities since it would only bring a short-term good reputation and even potentially be a threat for them in the future. Indeed, as a social investment, the Corporate Social Responsibility (CSR) activities that are run for a long time will provide them with a business 'change' or 'return' in the form of profit for the company. The method used to measure the social impact of the CSR activities was Social Return on Investment (SROI) which not only could calculate the value of profits in the form of money, but included a broader concept covering social, economic and environmental values. The results of this study reveal that Sentra Industri Bukit Asam (SIBA) Batik Kujur Program that was initiated based on culture (history) has produced economic and business values for service users in the society. This resulted in a social investment impact value in the form of SROI Ratio of 5.39, which means that for every investment made by PTBA with Rp. 1,- they will get impact or benefit worth Rp. 5.39,-. Therefore, it can be seen from the social and economic values that the Sentra Industri Bukit Asam (SIBA) Batik Kujur Program is feasible and successful.
\end{abstract}

Keywords: Social Return On Investment (SROI), Corporate Social Responsibility (CSR), Impact Of Social Investment, Batik Kujur

\section{SOCIAL RETURN ON INVESTMENT (SROI) PROGRAM "SENTRA INDUSTRI BUKIT ASAM" (SIBA) DUSUN BATIK KUJUR TANJUNG ENIM}

\begin{abstract}
ABSTRAK
Kegiatan corporate social responsibility (CSR) yang dilakukan perusahaan idealnya dilaksanakan sebagai sebuah investasi sosial, bukan sekedar kegiatan yang bersifat sementara untuk menunjukkan tanggung jawab saja, karena hal demikian hanya akan mendatangkan citra baik sesaat dan akan menjadi ancaman bagi perusahaan di kemudian hari. Sebagai sebuah investasi sosial, pelaksanaan kegiatan CSR dalam jangka panjang akan mendatangkan "kembalian" (return) bisnis berupa profit bagi perusahaan. Metode yang digunakan untuk mengukur dampak sosial dari kegitan CSR adalah dengan menggunakan social return on investment (SROI) yang tidak hanya menghitung nilai keuntungan berupa uang saja, melainkan mencakup konsep yang lebih luas yaitu meliputi nilai sosial, ekonomi dan juga lingkungan. Hasil kajian menunjukkan bahwa Program Sentra Industri Bukit Asam (SIBA) Batik Kujur yang diinisiasi dengan berbasis pada budaya (sejarah) telah menghasilkan nilai ekonomi dan bisnis bagi masyarakat penerima program, yaitu menghasilkan nilai dampak investasi sosial berupa SROI Rasio sebesar 5,39 artinya bahwa setiap investasi yang dilakukan oleh PTBA sebesar Rp. 1,- memperoleh dampak atau manfaat senilai Rp. 5,39,-. Bila ditinjau dari sisi sosial dan ekonomi, maka program Sentra Industri Bukit Asam (SIBA) Batik Kujur dapat dikatakan layak dan berhasil.
\end{abstract}

Kata kunci: Social Return On Investment (SROI), Corporate Social Responsibility (CSR), Dampak Investasi Sosial, Batik Kujur

AdBispreneur : Jurnal Pemikiran dan Penelitian Administrasi Bisnis dan Kewirausahaan

Vol.5, No. 1, April 2020, DOI : https://doi.org/10.24198/adbispreneur.v5i1.26069, hal. 15-29 


\section{PENDAHULUAN}

Kegiatan dunia usaha ditujukan untuk mencari keuntungan (profit) sebagai tanggung jawab utama pengusaha terhadap para penanam modal (shareholder), hal ini seperti yang diungkapkan oleh et al. (2018). Namun demikian, sejalan dengan mandat peraturan perundangan yang berlaku di Indonesia yang mengatur kegiatan usaha perseroan terbatas sebagai salah satu bentuk badan hukum dari kegiatan usaha, di mana perseroan terbatas diwajibkan untuk melaksanakan tanggung jawab sosial perusahaan atau yang sering disebut dengan istilah corporate social responsibility (CSR).

Pelaksanaan CSR oleh perusahaan selain sebagai sebuah kewajiban, sebagian perusahaan memandang pelaksanaan CSR sebagai kebutuhan, yaitu sebagai wujud nyata perhatian yang diberikan oleh perusahaan kepada para pemangku kepentingan (stakeholder), terutama guna membangun dan menjaga hubungan baik diantara perusahaan dengan masyarakat di sekitar perusahaan.

Sebagai aktivitas sosial, kegiatan CSR dilaksanakan dengan berdasarkan pada nilai keuntungan yang diperoleh perusahaan. Sebagai sebuah investasi, kegiatan CSR yang dilaksanakan oleh perusahaan pun harus dapat dihitung dan tentunya diharapkan dapat mendatangkan keuntungan bagi perusahaan. Dengan demikian, dana yang dikeluarkan oleh perusahaan untuk melaksanakan kegiatan CSR tidak lagi dianggap sebagai pengeluaran yang tidak berkembalian bagi perusahaan, terlebih dianggap sebagai tindakan pemborosan, karena setiap nilai rupiah yang dikeluarkan oleh perusahaan sebagai investasi sosial dalam kegiatan CSR dapat dihitung nilai pengembaliannya sebagai bentuk keuntungan bagi perusahaan baik secara finansial maupun berupa social value.

Salah satu metode yang dapat digunakan untuk menghitung nilai kembalian dari investasi sosial yang dilakukan oleh perusahaan adalah dengan menggunakan metode Social Return on Investment (SROI), yaitu metode yang akan membantu perusahaan untuk dapat menghitung nilai kembalian dari investasi sosial yang diperoleh perusahaan rangka mendukung terwujudnya sustainable development karena dengan menggunakan metode SROI setiap program akan diukur efektivitasnya dengan mengacu kepada dampak yang dihasilkan setelah program tersebut berjalan (Santoso et al., 2018).

Sebagai sebuah perusahaan yang bergerak dalam bidang ekstraktif, PT. Bukit Asam Tbk. (PTBA) telah menjadi center of change di tengah lingkungan sosialnya karena telah berhasil memicu perubahan sosial positif bagi masyarakat sekitar perusahaan. Hal tersebut dibuktikan dengan telah diraihnya penghargaan PROPER Emas sebanyak 6 (enam) kali berturutturut sejak tahun 2013 hingga tahun 2018 yang diberikan oleh Kementerian Lingkungan Hidup.

Dengan diperolehnya PROPER Emas, hal tersebut menunjukkan bahwa PTBA sebagai perusahaan ekstraktif telah secara serius melakukan proses pelaporan kinerja kepada berbagai pihak terkait dan PROPER Emas adalah bentuk penghargaan pada perusahaan karena PTBA telah melaksanakan aktivitas bisnisnya secara ramah terhadap lingkungan, memperhatikan kelestarian lingkungan hidup di sekitarnya, dan memiliki concern terhadap pemerintah dan juga memperhtikan masyarakat.

Hal tersebut sejalan dengan pandangan Rusdin (2016) yang menyatakan bahwa perusahaan semakin terdorong untuk melakukan pelaporan sosial (social report) sebagai sebuah langkah strategis dalam membentuk kesadaran bagi perusahaan terhadap pentingnya mengimplementasikan program CSR sebagai bagian dari strategi bisnisnya.

Seiring perjalanan waktu, semakin banyak perusahaan yang mengungkap informasi CSR mereka dalam laporan tahunannya (Pang, 1982; Guthrie, 1982; Gray, 1990; Gray et al, 1993; Sayekti, 1994; Kroyan, 2006). Hasil kajian yang dilakukan oleh the Economist Intelligence Unit (2015) dalam Rusdin (2016) mengungkapkan bahwa 85\% investor dan eksekutif senior perusahaan menjadikan CSR sebagai pertimbangan utama mereka dalam mengambil keputusan.

Sebagai salah satu bentuk keseriusan PTBA dalam melaksanakan kegiatan CSR, PTBA telah menyusun rencana strategis CSR (RENSTRA CSR) yang telah diproyeksikan pada tahun 2019-2023. Salah satu program unggulan dalam RENSTRA CSR PTBA adalah bidang sosial budaya. PTBA memandang dinamika kehidupan bermasyarakat beserta 
kebudayaannya merupakan hal penting bagi perusahaan karena dengan memperhatikan kebudayaan masyarakat, maka program CSR PTBA khususnya akan sinergis dengan budaya masyarakat dan secara lebih luas hal tersebut akan mendukung kegiatan usaha perusahaan. Masyarakat di wilayah Tanjung Enim beragam secara etnis dan latar belakang budaya, sehingga menimbulkan corak budaya lokal yang berbedabeda. Kekayaan ini penting untuk dipelihara karena di dalamnya terkandung banyak hal yang bermanfaat, mengandung nilai-nilai kebijaksanaan dalam kehidupan dan mengajarkan pola berinteraksi secara harmonis dengan alam.

Hal tersebut didukung oleh kondisi geografis Kecamatan Muara Enim yang terletak di bagian barat wilayah Kabupaten Muara Enim dengan luas wilayah sekitar 185,91 $\mathrm{km}^{2}$. Kecamatan Muara Enim berbatasan di sebelah utara dengan Kecamtan Ujan Mas, sebelah selatan dengan Kecamatan Lawang Kidul, sebelah timur dengan Kecamatan Gunung Megang dan di sebelah barat dengan Kecamatan Lahat. Kawasan Muara Enim merupakan pertemuan dua aliran sungai besar, yaitu sungai Enim dan sungai Lematang. Selain itu, terdapat pula beberapa sungai kecil disekitarnya, yaitu sungai Samat, sungai Kepur, sungai Aur, sungai Bahu, sungai Temberau, dan sungai Lagan (Badan Pusat Statistik, 2018).

Secara historis, perjalanan sejarah telah mengungkapkan bahwa daerah sepanjang aliran sungai merupakan kawasan perkembangan kebudayaan bagi peradaban umat manusia, begitupun dengan kawasan Muara Enim. Orang datang dan pergi untuk mencari sumber kehidupan dan pemenuh kebutuhan hidup di pinggiran aliran sungai, seperti yang terjadi pula di kawasan sungai-sungai di Muara Enim, manusia membangun peradaban dengan membentuk masyarakat dan mengembangkan nilai-nilai kebudayaannya di sepanjang aliran sungai. Berdasarkan situasi yang demikian, kebudayaan dan nilai-nilai masyarakat pun tumbuh berkembang di sana yang salah satunya adalah nilai-nilai yang tertuang dalam Batik Kujur sebagai hasil karya kebudayaan masyarakat asli wilayah Kecamatan Muara Enim yang diwariskan dari satu generasi ke generasi berikutnya, hingga saat ini.

Sebagai sebuah inisiasi baru dalam pendekatan pelaksanaan program CSR yang berangkat dari aspek budaya (sejarah) untuk menghasilkan aspek ekonomi, rasio SROI tersebut sudah cukup besar menghasilkan dampak sosial. Tantangan berikutnya yang sangat penting untuk dilakukan oleh PTBA dan stakeholder lainnya adalah menjaga keberlanjutan dan kualitas dari Program SIBA Batik Kujur.

Sebagai perusahaan yang telah lama hidup dan berdampingan dengan masyarakat sekitar, PTBA diposisikan sebagai pihak yang memiliki kekuatan sumber daya, khususnya dalam hal pendanaan dan sumber bantuan finansial bagi masyarakat sekitar.

Berbagai program CSR yang dilakukan oleh perusahaan (tidak hanya oleh PTBA) seringkali mengikuti trend yang berkembang, yaitu dengan mengedepankan program berbasis ekonomi dan bisnis dengan tujuan secara langsung menghasilkan nilai ekonomi bagi masyarakat. Namun, justru seringkali hal tersebut melemahkan potensi yang dimiliki oleh masyarakat untuk dapat mandiri serta berpotensi memunculkan beragam potensi konflik di tengah masyarakat, baik itu berupa kecemburuan pada saat mendapatkan bantuan ataupun kondisi ketidakpercayaan masyarakat kepada pemerintah sebagai mediator antara perusahaan dengan masyarakat sebagai penerima program.

Berbagai situasi tersebut berbeda kondisinya dengan pelaksanaan Program SIBA Batik Kujur yang diinisiasi oleh Tim CSR PTBA. Program SIBA Batik Kujur diinisiasi dengan berbasis budaya (sejarah) yang kemudian menghasilkan nilai ekonomi dan bisnis bagi masyarakat penerima program. Basis budaya (sejarah) menjadi landasan nilai filosofis dalam pelaksanaan Program SIBA Batik Kujur yang pada titik tertentu akan berfungsi sebagai value yang akan menumbuhkan kebanggaan dan media yang akan mempersatukan masyarakat setempat karena masyarakat tentunya merasa memiliki nilai-nilai budaya dan sejarah yang sama. Di sisi lain, dipilihnya produksi batik karena selain mengandung nilai komoditas budaya, kain batik pun memiliki nilai ekonomi yang tinggi bagi masyarakat.

Perubahan kondisi masyarakat yang terjadi dengan dilaksanakannya Program SIBA Batik Kujur dapat digambarkan berdasarkan kondisi masyarakat Dusun Tanjung di mana pada awalnya dinilai kurang baik, terutama pada 
aspek sosial dan ekonomi. Kondisi kohesivitas pada masyarakat dirasa rendah, bahkan rentan terjadi pergesekan hingga menyebabkan konflik, kondisi tingkat ekonomi masyarakat pun rendah dan menjadikan masyarakat seringkali mengembangkan cara-cara yang tidak kooperatif dalam rangka mendapatkan perhatian dan bantuan dari perusahaan. Dusun Tanjung merupakan dusun yang letaknya sangat dekat dengan lokasi perusahaan, sehingga warga masyarakat Dusun Tanjung seringkali secara langsung menyampaikan tuntutan mereka pada perusahaan dan meminta perusahaan untuk membantu memenuhi berbagai kebutuhan mereka. Di sisi lain, perilaku dan mekanisme masyarakat dalam mempertahankan diri dalam memenuhi kebutuhan sehari-hari dilakukan seringkali dengan cara menghutang ke warungwarung, karena kondisi pendapatan masyarakat yang terhitung rendah dalam memenuhi kebutuhan.

Berdasarkan berbagai fenomena tersebut, dengan dilakukannya Program SIBA Batik Kujur, berbagai kondisi tersebut menjadi berubah, masyarakat yang tergabung dalam kelompok pengrajin SIBA Batik Kujur mengungkapkan bahwa telah terjadi perubahan dalam kehidupan keluarga mereka. Penghitungan SROI ini menunjukkan angka perubahan yang diperoleh sebagai bentuk "kembalian" (return) dari program CSR yang telah dilaksanakan oleh PTBA.

\section{TINJAUAN PUSTAKA}

\section{Corporate Social Responsibility (CSR)}

Corporate social responsibility (CSR) dalam perkembangannya dimaknai oleh pengusaha sebagai peluang dunia usaha untuk meningkatkan daya saing dan juga sebagai bagian dari upaya pengelolaan risiko guna mewujudkan sustainability kegiatan usaha yang dilakukan oleh perusahaan (Cahya, 2014).

Hal tersebut sejalan dengan konsep yang diusung oleh legitimacy theory bahwa kelangsungan hidup perusahaan bergantung pada hubungan antara perusahaan dengan masyarakat dan lingkungan sosial di mana perusahaan berada. Haniffa et al. (2005) menyatakan hal dalam pandangannya bahwa dalam aktivitasnya perusahaan memiliki kontrak dengan masyarakat, yaitu untuk melakukan kegiatan usaha berdasarkan nilai-nilai justice serta bagaimana perusahaan dapat menanggapi berbagai kelompok kepentingan (stakeholder) untuk melegitimasi tindakan perusahaan. Bahkan jika antara sistem nilai yang dianut oleh perusahaan terdapat ketidakselarasan dengan sistem nilai di dalam masyarakat, maka hal ini akan menghilangkan legitimasi perusahaan dan dapat mengancam kelangsungan hidup perusahaan (Haniffa et al., 2005).

Upaya menghubungkan dan mensinergiskan kedua konsep tersebut yaitu antara pelaksanaan corporate social responsibility (CSR) oleh perusahaan dengan social legitimacy dari masyarakat seringkali sulit untuk dilakukan dalam pelaksanaannya di lapangan, terlebih untuk dapat dipahami sesuai nilai filosofisnya. Hal tersebut terutama ketika perusahaan sedang berada dalam posisi dan situasi di tengah hiruk pikuk berbagai macam permasalahan dan tuntutan masyarakat sekitar perusahaan ataupun berbagai kelompok kepentingan (stakeholder), sehingga seringkali perusahaan mengambil jalan pintas yang dirasa cepat dan mudah untuk dilakukan, yaitu dengan memberikan dan memenuhi berbagai tuntutan yang diminta.

Tentunya hal tersebut tidak salah, namun jika hal ini terus terjadi dan berulang, maka di kemudian hari akan menjadi ancaman bagi perusahaan karena masyarakat ataupun kelompok kepentingan (stakeholder) menjadi bergantung dan bahkan akan berani mengancam perusahaan jika keinginan dan tuntutan mereka tidak diikuti untuk dipenuhi. Dalam situasi demikian, perusahaan akan memandang bahwa dana yang dikeluarkannya dalam kegiatan CSR adalah bentuk buang-buang dan memboroskan uang perusahaan, sehingga dinilai tidak bermanfaat terlebih menguntungkan (mendatangkan profit) bagi perusahaan, layaknya sebuah investasi sosial, kecuali mendatangkan citra baik sesaat bagi perusahaan. Idealnya, setiap kegiatan CSR yang dilakukan oleh perusahaan dapat dijadikan sebagai sebuah investasi sosial oleh perusahaan yang akan mendatangkan keuntungan (profit) di kemudian hari. Hal ini persis seperti kegiatan investasi bisnsi pada umumnya yang hanya dalam waktu jangka panjang saja kecenderungan hasilnya baru akan dapat dilihat dan diperoleh, tidak dalam jangka pendek.

Dengan demikian, diperlukan cara 
pandang investasi sosial bagi perusahaan dalam melaksanakan kegiatan CSR-nya, yaitu seperti yang diungkapkan oleh Jalal dan Kurniawan (2013): Pertama, cara berpikir dari "membuang uang" terutama bagi perusahaan yang memandang kegiatan CSR sebagai cost center dan upaya "pemadam kebakaran" menjadi "mengembangkan sumber daya", karena setiap sumber daya yang dipergunakan dalam kegiatan usaha harus dipertanggungjawabkan. Kedua, paradigma investasi sosial menekankan pada keuntungan yang akan diperoleh investornya yaitu perusahaan, bukan hanya untuk keuntungan penerima manfaatnya saja yaitu masyarakat, sehingga kegiatan CSR yang dilakukan perusahaan ditujukan sebagai upaya untuk meningkatkan kualitas hidup dan kapasitas masyarakat penerima program.

Sebagai sebuah investasi yaitu investasi sosial, maka perusahaan pun dapat melakukan upaya penghitungan nilai dampak sosial sebagai keuntungan dari investasi sosial yang telah dilakukannya dalam kegiatan CSR. Salah satu metode yang dapat diguankan untuk mengukur dampak sosial sebagai bentuk "kembalian" binsis (profit) dari investasi sosial yang dilakukan adalah dengan menggunakan metode social return on investment (SROI) yang tidak hanya menghitung nilai uang saja, melainkan juga mengukur konsep yang lebih luas, yaitu meliputi nilai sosial, ekonomi dan lingkungan (Purwohedi, 2016).

\section{Social Retun on Investment (SROI)}

Proses pengukuran dampak dari dilaksanakannya Program SIBA Batik Kujur ini menggunakan metode social return on investment (SROI). Sejalan dengan yang diungkapkan oleh Brouwers, J., Prins, E., Salverda, M. Herder, J, and Reynolds, E. (2010) bahwa SROI adalah sebuah pendekatan yang digunakan untuk mengukur dan menghitung dari konsep nilai yang lebih luas, yaitu untuk mengukur bentuk perubahan yang terjadi dalam kaitannya dengan hasil kegiatan sosial, keberadaan lingkungan, perubahan dalam hal ekonomi dan berbagai kemungkinan lainnya. Metode SROI mendasarkan penilaiannya atas nilai dari pengembalian keuangan yang dihargai oleh sebuah persepsi dan pengalaman dari para pemangku kepentingan (stakeholders) yang terlibat dalam program yang dilakukan, yaitu guna mencari indikator kunci dari setiap hal yang telah berubah dan setiap pihak diminta untuk menceritakan kisah perubahan ataupun berbagai efek yang terjadi dan jika memungkinkan menggunakan nilai moneter (monetisasi) berupa perhitungan-perhitungan tertentu sebagai indikatornya. Dengan memonetisasi berbagai indikator tersebut, maka ekuivalen dari finansial yang dimaksud dalam pengembalian sosial dan lingkungan akan tercipta.

Pelibatan berbagai stakeholder dalam
proses pengukuran dampak dari dilaksanakannya Program SIBA Batik Kujur merupakan hal penting yang harus dilakukan, hal ini sejalan dengan pendapat Scholten P., Nicholls, J., Olsen S. \& Galimidi, B. (2006). Dalam pelaksanaan pengukuran dampak dari Program SIBA Batik Kujur ini melibatkan berbagai stakeholder utama (primary stakeholder) yang secara langsung terlibat dalam pelaksanaan Program SIBA Batik Kujur, yaitu yang terdiri dari: (1). Pihak PTBA selaku pelaksana kegiatan CSR dan penggagas program SIBA Batik Kujur; (2). Pihak Pemerintahan Kecamatan Lawang Kidul, yaitu selaku institusi pemerintah yang memiliki kewenangan dalam melakukan pembangunan di kawasan Dusun Tanjung dan juga selaku konsumen dari produk kelompok binaan SIBA Batik Kujur; (3). Kelompok-kelompok SIBA Batik Kujur, yaitu berjumlah 5 (lima) kelompok.

Penghitungan dampak sosial dengan menggunakan metode social return on investment (SROI) melipatkan para pemangku kepentingan (stakeholder) dari satu program yang akan dianalisis, yaitu untuk mengeksplorasi berbagai dampak yang dirasakan setelah program dijalankan.

\section{METODE PENELITIAN}

Beberapa teknik pengumpulan data yang dilakukan dalam proses pengukuran dampak dari dilaksanakannya Program SIBA Batik Kujur ini adalah dengan cara: (1). Melakukan wawancara mendalam (indepth interview), yaitu untuk mendapatkan data dari para stakeholder yang terlibat dalam pelaksanaan Program SIBA Batik Kujur; (2). Melakukan focus group discussion (FGD) yang melibatkan tim CSR PTBA selaku inisiator program dan juga anggota kelompok SIBA Batik Kujur; (3). Melakukan proses observasi terhadap dinamika kelompok, alat produksi dan produk yang dihasilkan; (4). Melakukan teknik studi literatur terhadap 
berbagai data sekunder dan dokumentasi yang dimiliki oleh PTBA dan juga kelompok SIBA Batik Kujur terkait keberadaan dan perkembangan Program SIBA Batik Kujur, serta mengkaji berbagai literatur lainnya yang terkait dan mendukung dilaksanakannya kajian dengan menggunakan metode SROI; dan (5). Melakukan studi dokumentasi terhadap berbagai dokumen yang berkaitan dengan Program SIBA Batik Kujur. Adapun instrument yang digunakan dalam proses pengumpulan data di lapangan adalah berupa pedoman wawancara.

Proses pengukuran dampak dari dilaksanakannya Program SIBA Batik Kujur yang dilaksanakan oleh Tim CSR PTBA tanpa adanya intervensi dari pihak lain. Hal ini penting dinyatakan sejak awal untuk dapat menilai kelayakan desain program, implementasi dan dampak yang dirasakan oleh masyarakat.

Berdasarkan proses pengumpulan data di lapangan yang dilakukan dengan teknik wawancara mendalam (indept interview) dan focus group discussion (FGD) dengan para informan yang terdiri dari Tim CSR PTBA, pihak pemerintahan setempat dan kelompok pengrajin SIBA Batik Kujur diperoleh data bahwa para pihak yang terlibat (stakeholder) dalam pelaksanaan Program SIBA Batik Kujur adalah seperti yang tertuang pada tabel 1 mengenai pemetaan dan analisis stakeholder, yaitu sebagai berikut :

Tabel 1

Pemetaan dan Analisis Stakeholder

\begin{tabular}{|c|c|c|}
\hline No. & $\begin{array}{l}\text { Pemangku Kepentingan } \\
\text { (Stakeholder) }\end{array}$ & Peran Dalam Program \\
\hline 1. & $\begin{array}{l}\text { Kelompok pengrajin SIBA Batik } \\
\text { Kujur }\end{array}$ & $\begin{array}{l}\text { Kelompok sebagai media yang digunakan untuk } \\
\text { mempermudah dalam peningkatan pengetahuan, } \\
\text { pendampingan, penyaluran bantuan (alat dan bahan), } \\
\text { monitoring dan evaluasi program }\end{array}$ \\
\hline 2. & $\begin{array}{l}\text { Pengrajin Batik Kujur (sebagai } \\
\text { individu) }\end{array}$ & $\begin{array}{l}\text { Sebagai subjek pelaksana program yang diarahkan untuk } \\
\text { berdaya dan mandiri }\end{array}$ \\
\hline 3. & Keluarga & $\begin{array}{l}\text { Memberikan dukungan dalam pelatihan dan produksi Batik } \\
\text { Kujur }\end{array}$ \\
\hline 4. & Masyarakat & $\begin{array}{l}\text { Sebagai konsumen dan mendukung pengembangan Kampung } \\
\text { Batik Kujur }\end{array}$ \\
\hline 5 & Supplier alat dan bahan & Penyedia alat dan bahan produksi Batik Kujur \\
\hline 6. & $\begin{array}{l}\text { Pelatih Batik (Tim Omah Kreatif } \\
\text { Dongaji) }\end{array}$ & $\begin{array}{l}\text { Memberi pengetahuan, keterampilan dan pendampingan } \\
\text { dalam produksi Batik Kujur }\end{array}$ \\
\hline 7. & Ekspedisi Pengiriman & Penyedia jasa pengiriman pesanan alat dan bahan \\
\hline 8. & Perbankan & $\begin{array}{l}\text { Sebagai tempat menyimpan dan pencatatan sirkulasi } \\
\text { keuangan kelompok dan pengrajin (sebagai individu) terkait } \\
\text { produksi Batik Kujur, yang akan diperlukan pada saat audit } \\
\text { atau monitoring evaluasi dari pihak terkait }\end{array}$ \\
\hline 9. & Konsumen & $\begin{array}{l}\text { Sebagai pengguna produk dan penjamin keberlangsungan } \\
\text { produksi Batik Kujur }\end{array}$ \\
\hline 10. & Pemerintah & $\begin{array}{l}\text { Sebagai pendukung dalam hal kebijakan pemberdayaan } \\
\text { masyarakat dan pengguna produk Batik Kujur }\end{array}$ \\
\hline 11. & PTBA & $\begin{array}{l}\text { Sebagai inisiator program, donor program dan konsumen } \\
\text { Batik Kujur }\end{array}$ \\
\hline
\end{tabular}

Sumber: Raharjo, S. T. (2019)

Validasi data dilakukan dengan proses triangulasi, yaitu dengan menggunakan triangulasi sumber dan triangulasi metode untuk meminimalisir bias data. Berbagai data yang diperoleh kemudian diolah dan dianalisis dengan beberapa tahapan, mulai dari proses mengkaji catatan lapangan, pembuatan transkrip wawancara, reduksi data, kategorisasi data, klasifikasi data dan display data.

Proses analisis data dilakukan dalam dua 
tahapan, yaitu proses analisis yang dilakukan selama pengumpulan data dan proses analisis data yang dilakukan setelah proses pengumpulan data selesai dilakukan.

1) Analisis data selama pengumpulan data yaitu proses analisis data yang dilakukan oleh peneliti selama proses pengumpulan data berlangsung, melalui proses berpikir yang dilakukan oleh peneliti pada saat proses pengumpulan dan penggalian data di lapangan terkait data yang sudah didapatkan, sehingga membuat peneliti kemudian melakukan probbing (penggalian data) terhadap informan dan juga mengembangkan strategi untuk mengumpulkan data lainnya yang belum diperoleh.
2) Analisa data setelah pengumpulan data yaitu pada tahap ini peneliti melakukan analisa terhadap seluruh data yang telah diperoleh dan peneliti lebih banyak terlibat dalam kegiatan penyajian atau penampilan (display) data yang telah dikumpulkan dan telah dianalisis sebelumnya. Dalam tahap ini, peneliti banyak menyusun teks naratif. Adapun display data adalah format yang menyajikan informasi secara sistematik kepada stakeholder terkait.

Berdasarkan hasil pengolahan data dan analisis data, kemudian akan diperoleh perhitungan SROI dengan menggunakan rumus yang dikemukakan oleh Scholten P., Nicholls, J., Olsen S. \& Galimidi, B. (2006) sebagai berikut:

$$
\begin{gathered}
\text { NPV }=[\text { Present value of benefits }]-[\text { Value of investments }] \\
\text { SROI Ratio }=\text { Present Value } \\
\text { Value of Input }
\end{gathered}
$$

\begin{tabular}{|c|c|c|c|c|c|c|c|c|c|c|}
\hline $\begin{array}{l}\text { Present } \\
\text { Value }\end{array}$ & $=$ & $\begin{array}{l}\text { Value of } \\
\text { impact in } \\
\frac{\text { Year } 1}{(1+r)}\end{array}$ & + & $\begin{array}{l}\text { Value of } \\
\text { impact in } \\
\frac{\text { Year } 2}{(1+r)^{2}}\end{array}$ & + & $\begin{array}{l}\text { Value of } \\
\text { impact in } \\
\frac{\text { Year } 3}{(1+r)^{3}}\end{array}$ & + & $\begin{array}{l}\text { Value of } \\
\text { impact in } \\
\frac{\text { Year } 4}{(1+r)^{4}}\end{array}$ & + & $\begin{array}{l}\text { Value of } \\
\text { impact in } \\
\frac{\text { Year } 5}{(1+r)^{5}}\end{array}$ \\
\hline
\end{tabular}

Adapun untuk data multy years rumus yang digunakan adalah:

Perhitungan nilai rasio SROI minimum dilakukan dalam jangka waktu 5 (lima) tahun, sehingga setelah mendapatkan data perhitungan dampak monetisasi di tahun pertama, dampak sosial tersebut diproyeksikan ke 4 (empat) tahun berikutnya, sehingga menjadi total dalam jangka waktu 5 (lima) tahun.

\section{HASIL DAN PEMBAHASAN}

Berdasarkan kajian di lapangan, diperoleh hal-hal penting sebagai berikut:

1) Bahwa untuk mendorong masyarakat agar berdaya dan mandiri, diperlukan suatu daya tarik yang akan memiliki efek lebih permanen. Dibandingkan dengan pertimbangan aspek ekonomi secara langsung, ternyata aspek budaya atau sejarah bukan hanya bisa menghasilkan nilai ekonomi, tetapi juga mampu mendorong hubungan yang lebih kuat dan menumbuhkan kreativitas di dalam masyarakat.

2) Kondisi ibu-ibu yang semula merasa kurang berpendidikan, tidak memiliki pekerjaan, ternyata setelah bergabung ke dalam kelompok pengrajin SIBA Batik Kujur menjadi percaya diri dan memiliki kemampuan untuk menghasilkan karya batik yang memiliki nilai ekonomi.

3) Kegiatan produksi batik yang bersifat kolektif (dalam bentuk kelompok) bukan hanya memudahkan dalam proses pengelolaan program CSR saja, melainkan juga mampu lebih menumbuhkan hubungan yang lebih erat di antara sesama anggota kelompok yang saling bertetangga. Bahkan mampu menumbuhkan kemampuan untuk mengambil pelajaran positif dari kesalahan yang diperbuat anggota. 
4) Pada prinsipnya, setiap kemampuan bisa dibangun terlepas dari kondisi awal yang dimiliki selama ada pihak yang secara jujur dan tulus mau mengembangkan kapasitas masyarakat yang didukung oleh kemauan dari masyarakat (anggota kelompok).

5) Program SIBA Batik Kujur telah menumbuhkan dan mengembangkan berbagai kegiatan usaha lainnya, yang tampak pada kegiatan usaha supplier, ekspedisi pengiriman dan juga perbankan.

Adapun penghitungan dampak sosial dari Program SIBA Batik Kujur yang dilakukan dengan berdasarkan pada nilai-nilai riil yang diperoleh selama proses pengumpulan data di lapangan; diantaranya kebutuhan pokok keluarga per bulan, upah kerja minimum harian, dan harga-harga yang tercatat pada dokumen bukti pembayaran pembelian alat dan bahan produksi batik.

Terkait penetapan harga untuk biaya ekspedisi pengiriman dalam penghitungan SORI ini disesuaikan dengan tariff ongkos kirim barang dengan mengacu pada tarif harga yang tercatat pada website terkait yaitu pada halaman Cektarif.com. (n.d.).

Tabel 2

Calculating Impact of Evidence

\begin{tabular}{|c|c|c|c|c|}
\hline No. & Dampak & Pendekatan Perhitungan & $\begin{array}{c}\text { Pendekatan } \\
\text { Monetisasi }\end{array}$ & $\begin{array}{c}\text { Sumber } \\
\text { Informasi }\end{array}$ \\
\hline \multicolumn{5}{|c|}{ A. Pengrajin Batik Kujur (sebagai individu) } \\
\hline 1. & $\begin{array}{l}\text { Peningkatan } \\
\text { pendapatan }\end{array}$ & $\begin{array}{l}\text { Kapasitas produksi perbulan } \\
\text { per orang: } 20 \text { lembar panjang } \\
3,5 \text { meter }\end{array}$ & $\begin{array}{l}\text { Kapasitas produksi per } \\
\text { bulan X } 12 \text { bulan X } \\
\text { keuntungan per lembar } \\
\text { X jumlah pengrajin }\end{array}$ & Indept interview \\
\hline 2. & $\begin{array}{l}\text { Pemenuhan } \\
\text { kebutuhan harian } \\
\text { dalam keluarga }\end{array}$ & $\begin{array}{l}\text { Kebutuhan harian minimum } \\
\text { dalam keluarga; rerata Rp. } \\
1.500 .000 \text { per bulan per } \\
\text { keluarga }\end{array}$ & $\begin{array}{l}\text { Kebutuhan harian: } \\
\text { biaya perbulan X } 12 \\
\text { bulan X } 25 \text { keluarga }\end{array}$ & Indept interview \\
\hline 3. & $\begin{array}{l}\text { Terhindar dari } \\
\text { ketakutan ditagih } \\
\text { hutang, kemampuan } \\
\text { membayar hutang }\end{array}$ & $\begin{array}{l}\text { Nilai hutang dihitung } \\
\text { berdasarkan kebutuhan } \\
\text { pokok minimum keluarga; } \\
\text { rerata Rp. } 1.500 .000 \text { per } \\
\text { bulan per keluarga }\end{array}$ & $\begin{array}{l}\text { Kebutuhan keluarga: } \\
\text { biaya perbulan X } 12 \\
\text { bulan X } 25 \text { keluarga }\end{array}$ & Indept interview \\
\hline 4. & $\begin{array}{l}\text { Bisa berbagi dengan } \\
\text { pihak lain (anggota } \\
\text { keluarga, teman, } \\
\text { saudara) }\end{array}$ & $\begin{array}{l}\text { Kemampuan berbagi rerata: } \\
\text { Rp. } 100.000 \text { per bulan per } \\
\text { orang }\end{array}$ & $\begin{array}{l}\text { Berbagi: rerata berbagi } \\
\text { perbulan X } 12 \text { bulan } X \\
25\end{array}$ & Indept interview \\
\hline 5. & $\begin{array}{l}\text { Bisa membiayai } \\
\text { pendidikan anak }\end{array}$ & $\begin{array}{l}\text { Biaya pendidikan dalam hal } \\
\text { ini berupa ongkos berangkat } \\
\text { ke sekolah: rerata Rp. } 20.000 \\
\text { per hari per anak. Setiap } \\
\text { anggota keluarga } \\
\text { diasumsikan rerata memiliki } \\
\text { anak sekolah sebanyak } 1 \\
\text { orang, jumlah hari dalam } 1 \\
\text { bulan pergi ke sekolah rerata } \\
25 \text { hari }\end{array}$ & $\begin{array}{l}\text { Ongkos perhari X } 25 \\
\text { hari X } 25 \text { anggota X } \\
12 \text { bulan X rerata } \\
\text { jumlah anak ( } 1 \text { orang) }\end{array}$ & Indept interview \\
\hline \multicolumn{5}{|c|}{ B. Masyarakat } \\
\hline 1. & $\begin{array}{l}\text { Kesediaan gotong } \\
\text { royong untuk } \\
\text { membangun }\end{array}$ & $\begin{array}{l}\text { Kegiatan gotong royong } \\
\text { rerata dilaksanakan } 1 \text { bulan } \\
\text { sekali, dilaksanakan rerata }\end{array}$ & $\begin{array}{l}\text { Satu bulan satu kali X } \\
12 \text { bulan X } 20 \text { orang X } \\
\text { upah kerja kuli harian }\end{array}$ & $\begin{array}{l}\text { Indept interview } \\
\text { dan FGD }\end{array}$ \\
\hline
\end{tabular}




\begin{tabular}{|c|c|c|c|c|}
\hline No. & Dampak & Pendekatan Perhitungan & $\begin{array}{c}\text { Pendekatan } \\
\text { Monetisasi }\end{array}$ & $\begin{array}{c}\text { Sumber } \\
\text { Informasi }\end{array}$ \\
\hline & $\begin{array}{l}\text { Kampung Batik } \\
\text { Kujur }\end{array}$ & $\begin{array}{l}\text { oleh } 20 \text { orang. Nilai tenaga } \\
\text { kerja gotong royong } \\
\text { disetarakan dengan nilai } \\
\text { terendah upah harian di } \\
\text { daerah setempat (Rp. } \\
100.000 \text { per hari) }\end{array}$ & & \\
\hline \multicolumn{5}{|c|}{ C. Supplier alat dan bahan } \\
\hline 1. & $\begin{array}{l}\text { Peningkatan } \\
\text { penjualan alat } \\
\text { produksi }\end{array}$ & $\begin{array}{l}\text { Satu tahun dilakukan } \\
\text { penggantian alat yang rusak } \\
\text { atau penambahan alat baru } \\
\text { berupa kompor dan kuali }\end{array}$ & $\begin{array}{l}\text { Satu set alat per tahun } \\
\text { X } 25 \text { orang X harga } \\
\text { alat }\end{array}$ & FGD \\
\hline \multirow[t]{2}{*}{2.} & \multirow[t]{2}{*}{$\begin{array}{l}\text { Peningkatan } \\
\text { penjualan bahan } \\
\text { produksi }\end{array}$} & $\begin{array}{l}\text { Rerata produksi } 20 \text { lembar } \\
\text { per bulan dengan ukuran } 3,5 \\
\text { meter. Keuntungan rerata } \\
\text { sebesar Rp. } 10.000 \text { per } \\
\text { lembar }\end{array}$ & $\begin{array}{l}\text { Kain: } 20 \text { lembar X } 25 \\
\text { orang X } 12 \text { bulan X } \\
\text { keuntungan }\end{array}$ & FGD \\
\hline & & $\begin{array}{l}\text { Rerata produksi } 20 \text { lembar } \\
\text { per bulan. Biaya satuan rerata } \\
\text { sebesar Rp. } 25.000 \text { per } \\
\text { lembar }\end{array}$ & $\begin{array}{l}\text { Bahan produksi (lilin, } \\
\text { pewarna, gas): } 20 \mathrm{X} \\
25 \mathrm{X} 12 \text { bulan X biaya } \\
\text { satuan }\end{array}$ & FGD \\
\hline \multicolumn{5}{|c|}{ D. Ekspedisi Pengiriman } \\
\hline \multirow[t]{3}{*}{1.} & \multirow[t]{3}{*}{$\begin{array}{l}\text { Peningkatan jasa } \\
\text { pengiriman alat dan } \\
\text { bahan }\end{array}$} & $\begin{array}{l}\text { Satu tahun dilakukan } \\
\text { penggantian alat yang rusak } \\
\text { atau penambahan alat baru } \\
\text { berupa kompor dan kuali. } \\
\text { Berat barang rerata } 8 \mathrm{~kg} \text {, } \\
\text { ongkos jasa pengiriman Rp. } \\
51.000 \text { per kilogram }\end{array}$ & $\begin{array}{l}\text { Berat alat yang } \\
\text { dipesan X } 25 \text { orang X } \\
\text { ongkos kirim per } \\
\text { kilogram }\end{array}$ & $\begin{array}{l}\text { FGD dan tarif } \\
\text { harga dalam } \\
\text { website }\end{array}$ \\
\hline & & $\begin{array}{l}\text { Rerata produksi } 20 \text { lembar } \\
\text { per bulan dengan ukuran } 3,5 \\
\text { meter. Ongkos jasa } \\
\text { pengiriman Rp. } 15.000 \text { per } \\
\text { lembar }\end{array}$ & $\begin{array}{l}\text { Kain: } 20 \text { lembar X } 25 \\
\text { orang X } 12 \text { bulan X } \\
\text { ongkos kirim per } \\
\text { lembar }\end{array}$ & Indept interview \\
\hline & & $\begin{array}{l}\text { Rerata kebutuhan bahan per } \\
\text { bulan } 5 \mathrm{~kg} \text { dengan ongkos } \\
\text { jasa pengiriman Rp. } 51.000 \\
\text { per kilogram }\end{array}$ & $\begin{array}{l}\text { Bahan produksi (lilin, } \\
\text { pewarna): perbulan X } \\
5 \mathrm{~kg} \text { X } 25 \text { orang X } \\
\text { ongkos kirim per } \\
\text { kilogram }\end{array}$ & Indept interview \\
\hline \multicolumn{5}{|c|}{ E. Perbankan } \\
\hline 1. & $\begin{array}{l}\text { Peningkatan } \\
\text { nasabah penabung }\end{array}$ & $\begin{array}{l}\text { Kemampuan menabung per } \\
\text { orang per bulan Rp. } 50.000\end{array}$ & $\begin{array}{l}\text { Kemampuan minimal } \\
\text { menabung X } 12 \text { bulan } \\
\text { X } 25 \text { orang }\end{array}$ & Indept interview \\
\hline \multicolumn{5}{|c|}{ F. Konsumen } \\
\hline 1. & $\begin{array}{l}\text { Rasa bangga } \\
\text { mempunyai batik } \\
\text { khas daerahnya } \\
\text { sendiri }\end{array}$ & $\begin{array}{l}\text { Asumsi orang membeli batik } \\
1 \text { tahun } 1 \text { kali dari } 10 \% \\
\text { penduduk Lawang Kidul } \\
\text { ( } 68.711 \text { orang, BPS } 2018 \text { ) } \\
\text { dan keuntungan jual rerata }\end{array}$ & $\begin{array}{l}\text { Satu lembar batik X } 5 \\
\% \text { jumlah penduduk X } \\
\text { keuntungan }\end{array}$ & Indept interview \\
\hline
\end{tabular}




\begin{tabular}{|c|c|c|c|c|}
\hline No. & Dampak & Pendekatan Perhitungan & $\begin{array}{c}\text { Pendekatan } \\
\text { Monetisasi }\end{array}$ & $\begin{array}{c}\text { Sumber } \\
\text { Informasi }\end{array}$ \\
\hline & & Rp. 25.000 per lembar & & \\
\hline
\end{tabular}

Sumber: Raharjo, S. T. (2019)

Berdasarkan penghitungan poin-poin SROI pada tabel 2, maka diperoleh poin-poin penting sebagai berikut:

1) Pembentukan kelompok pengrajin SIBA Batik Kujur dirasa telah meningkatkan kapasitas masyarakat, mulai dari peningkatan pengetahuan, memperbaiki sikap dan menambah keterampilan anggota kelompok yang berjumlah 5 (lima) kelompok dan masing-masing kelompok terdiri dari 5 (lima) orang warga.

2) Munculnya kerelaan anggota kelompok pengrajin SIBA Batik Kujur untuk keluar dari pekerjaan yang telah mereka lakukan sebelumnya. Kerelaan keluar dari pekerjaan sebelumnya tersebut muncul karena anggota kelompok memandang bahwa Program SIBA Batik Kujur akan memberikan pelung yang lebih baik bagi mereka, bukan hanya dalam kaitannya dengan peluang ekonomi, tetapi juga dipandang akan memberikan peluang dalam pengembangan aspek budaya dan sejarah yang berkaitan dengan Tanjung Enim. Terlebih pekerjaan membuat batik dilakukan di rumah, sehingga para ibu-ibu khususnya mendapatkan dukungan positif dari para suami mereka, karena selain dapat membatik dan mendapatkan tambahan penghasilan, para ibu pun tidak perlu meninggalkan pekerjaan pokok sebagai ibu dalam mengurus keluarga dan mengasuh anak di rumah.

3) Kegiatan membatik yang dilaksanakan secara berkelompok dirasa telah mendorong terwujudnya perubahan sikap yang positif di tengah kehidupan bermasyarakat, karena dengan berkegiatan bersama dalam membuat kain batik, setiap anggota kelompok berkesempatan untuk saling mengenal diantara sesama tetangganya, saling bekerjasama menciptakan rantai nilai yang positif dalam menyelesaikan pekerjaan yang dipesan oleh konsumen, tercipta sikap saling mengingatkan jika terjadi kesalahan ataupun permasalahan di dalam kelompok, saling berbagi pekerjaan dalam membatik.
Dengan demikian, dinamika yang terjadi di dalam kelompok telah mendorong setiap anggotanya untuk dapat mengambil sikap positif dari kesalahan yang terjadi pada saat membatik, yaitu sebagai sumber belajar bersama.

4) Perubahan yang secara langsung dirasakan oleh masyarakat secara lebih luas adalah bahwa mereka merasa bangga memiliki produk khas daerahnya sendiri, yaitu berupa Batik Kujur yang dapat ditawarkan bukan hanya pada masyarakat setempat, melainkan juga ditawarkan pada masyarakat Tanjung Enim yang sedang merantau di luar daerah, sehingga menarik mereka untuk memesan produk Batik Kujur. Bagi para anggota kelompok, mereka merasa bangga karena secara langsung terlibat dalam memproduksi Batik Kujur yang sekaligus dipandang oleh masyarakat sebagai upaya untuk melestarikan nilai budaya setempat.

5) Perubahan yang diungkapkan oleh anggota dengan bergabung dalam kelompok pengrajin SIBA Batik Kujur, adalah bahwa mereka mendapatkan tambahan penghasilan yang digunakan untuk membantu keluarga dalam memenuhi kebutuhan, menyekolahkan anak dan sudah mulai bisa menabung. Mereka pun terhindari dari hutang ke warung untuk memenuhi kebutuhan sehari-hari, bahkan sudah mulai bisa membantu saudara yang mengalami kesulitan dalam memenuhi kebutuhan keseharian.

6) Terbentuknya perilaku menabung pada anggota kelompok pengrajin SIBA Batik Kujur, hal ini menjadi modal awal munculnya nilai akuntabilitas dalam menjalankan kegiatan usaha. Dengan memiliki buku rekening tabungan di bank, hal ini akan bermanfaat bagi anggota kelompok sebagai sarana menyimpan uang dan pencatatan sirkulasi keuangan kelompok dan juga pengrajin (sebagai individu) terkait produksi Batik Kujur. Pencatatan keuangan pada bank ini akan diperlukan pada saat adanya audit kegiatan 
ataupun proses monitoring evaluasi program dari pihak-pihak terkait.

7) Para anggota kelompok menyatakan bahwa mereka merasa senang dapat bergabung ke dalam kelompok pengrajin SIBA Batik Kujur karena dapat mengubah kegiatan keseharian mereka yang biasanya hanya melakukan aktivitas urusan rumah tangga saja, dengan bergabung menjadi anggota kelompok SIBA Batik Kujur, mereka menjadi memiliki kegiatan rutin lain yang bukan hanya menghasilkan tambahan pendapatan bagi mereka, melainkan juga menambah pengetahuan, meningkatkan semangat mereka dalam menjalani kehidupan sehari-hari karena merasa memiliki sesuatu yang menjadi target bersama dalam kelompok, dan dapat memperluas pergaulan dan menambah rekanan usaha sebagai bentuk outcome dari dilaksanakannya Program SIBA Batik Kujur.

Berdasarkan uraian calculating impact of evidence di atas, berikut ini adalah implementasi cara pengukuran dan perhitungan rasio SROI Program SIBA Batik Kujur yang didasarkan pada data yang diperoleh di lapangan.

Tabel 3

Measuring Value and Calculating SROI

\begin{tabular}{|c|c|c|}
\hline No. & Outcome & Hasil hitungan \\
\hline \multirow[t]{6}{*}{1} & \multicolumn{2}{|c|}{ Pengrajin batik (sebagai personal) } \\
\hline & Peningkatan pendapatan & $\begin{array}{l}\text { Kapasitas produksi rerata } 20 \text { lembar per orang per bulan. } \\
\text { Keuntungan rerata per lembar Rp. } 75.000 \text {. Dalam waktu satu tahun } \\
\text { untuk } 25 \text { anggota, maka rumusannya sebagai berikut; Kapasitas } \\
\text { produksi per bulan per orang X satu tahun X keutungan per lembar } \\
\text { X jumlah anggota. } \\
=(20 \text { lembar) X (12 bulan) X (Rp. } 75.000) X(25 \text { orang }) \\
=\text { Rp. } \mathbf{4 5 0 . 0 0 0 . 0 0 0}\end{array}$ \\
\hline & $\begin{array}{l}\text { Terhindar dari ketakutan } \\
\text { ditagih hutang, Kemampuan } \\
\text { membayar utang }\end{array}$ & $\begin{array}{l}\text { Hutang terjadi rerata karena untuk memenuhi kebutuhan pokok } \\
\text { keluarga, dengan nilai rerata Rp. } 1.500 .000 \text { per bulan per keluarga. } \\
\text { Setelah memiliki pendapatan, bukan hanya dapat memenuhi } \\
\text { kebutuhan pokok, tetapi juga sekaligus terhindar dari ketakutan } \\
\text { ditagih hutang. Rumusan dilakukan sebagai berikut; kebutuhan } \\
\text { pokok per bulan per keluarga X } 12 \text { bulan X jumlah anggota } \\
\text { (keluarga). } \\
=(\text { Rp. } 1.500 .000) \text { X (12 bulan) X ( } 25 \text { keluarga) } \\
=\text { Rp. } \mathbf{4 5 0 . 0 0 0 . 0 0 0}\end{array}$ \\
\hline & $\begin{array}{l}\text { Pemenuhan kebutuhan } \\
\text { harian dalam keluarga }\end{array}$ & $\begin{array}{l}\text { Kebutuhan pokok keluarga rerata Rp. } 1.500 .000 \text { per bulan per } \\
\text { keluarga. Rumusan dilakukan sebagai berikut; kebutuhan pokok per } \\
\text { bulan per keluarga X } 12 \text { bulan X jumlah anggota (keluarga). } \\
=(\text { Rp. } 1.500 .000) \text { X ( } 12 \text { bulan) X ( } 25 \text { keluarga) } \\
=\text { Rp. 450.000.000 }\end{array}$ \\
\hline & $\begin{array}{l}\text { Bisa berbagi dengan pihak } \\
\text { lain (anggota keluarga, } \\
\text { teman) }\end{array}$ & $\begin{array}{l}\text { Setelah memiliki pendapatan dari penjualan batik, rerata } \\
\text { kemampuan untuk membantu anggota keluarga lain sebesar Rp. } \\
100.000 \text { per bulan per anggota. Dalam kurun waktu satu tahun, } \\
\text { perhitungan dilakukan sebagai berikut; kemampuan nembantu per } \\
\text { orang X } 12 \text { bulan X jumlah anggota. } \\
=\text { (Rp. } 100.000) X \text { (12 bulan) X ( } 25 \text { orang) } \\
=\text { Rp. 30.000.000 }\end{array}$ \\
\hline & $\begin{array}{l}\text { Bisa membiayai pendidikan } \\
\text { anak }\end{array}$ & $\begin{array}{l}\text { Biaya pendidikan dimaksud berupa ongkos berangkat ke sekolah, } \\
\text { rerata Rp. } 20.000 \text { per hari. Dengan asumsi dalam sebulan } 25 \text { hari } \\
\text { sekolah dan rerata tiap keluarga mempunyai anak sekolah } 1 \text { orang, } \\
\text { maka rumusan dilakukan sebagai berikut; ongkos per hari X jumlah } \\
\text { hari per bulan X } 12 \text { bulan X } 1 \text { anak sekolah X jumlah anggota. } \\
=\text { (Rp. } 20.000) X \text { ( } 25 \text { hari) X (12 bulan) X (1 anak) X (25 anggota) } \\
=\text { Rp. 150.000.000 }\end{array}$ \\
\hline \multirow[t]{2}{*}{2} & \multicolumn{2}{|l|}{ Masyarakat } \\
\hline & Kesediaan gotong rotong & Gotong royong rerata diikuti oleh 20 orang, dengan pelaksanaan 1 \\
\hline
\end{tabular}

AdBispreneur : Jurnal Pemikiran dan Penelitian Administrasi Bisnis dan Kewirausahaan 


\begin{tabular}{|c|c|c|}
\hline No. & Outcome & Hasil hitungan \\
\hline & $\begin{array}{l}\text { untuk membangun sentra } \\
\text { batik Kujur }\end{array}$ & $\begin{array}{l}\text { bulan satu kali. Nilai dari gotong royong disetarakan dengan upah } \\
\text { minimum setempat yaitu Rp. } 100.000 \text { per orang. Untuk satu tahun, } \\
\text { rumusan nilai gotong royong sebagai berikut; jumlah gotong } \\
\text { royong per bulan X } 1 \text { tahun X personal X upah harian. } \\
=(1 \text { kali) X ( } 12 \text { bulan) X ( } 20 \text { orang) X (Rp. } 100.000) \\
=\text { Rp. } 24.000 .000\end{array}$ \\
\hline \multirow[t]{3}{*}{3} & \multicolumn{2}{|l|}{ Supplier alat dan bahan } \\
\hline & $\begin{array}{l}\text { Peningkatan penjualan alat } \\
\text { produksi }\end{array}$ & $\begin{array}{l}\text { Alat pokok produksi batik berupa kompor dan kuali khusus seharga } \\
\text { Rp. } 750.000 \text {. Dengan asumsi alat rusak dalam setahun atau terjadi } \\
\text { penambahan alat dalam setahun. Kalkulasi dilakukan sebagai } \\
\text { berikut; Harga alat X } 1 \text { tahun X jumlah anggota. } \\
=\text { (Rp. } 750.000) X \text { ( } 1 \text { tahun) X (25 Orang) } \\
=\text { Rp. } \mathbf{1 8 . 7 5 0 . 0 0 0}\end{array}$ \\
\hline & $\begin{array}{l}\text { Peningkatan penjualan bahan } \\
\text { produksi }\end{array}$ & $\begin{array}{l}\text { Harga kain rerata Rp. } 25.000 \text { per lembar. Dengan kapasitas } \\
\text { produksi } 20 \text { lembar per bulan per orang, maka perhitungan } \\
\text { dilakukan sebagai berikut: harga kain per lembar X kapasitas } \\
\text { produksi X } 12 \text { bulan X jumlah anggota } \\
=(\text { Rp. } 25.000) \text { X ( } 20 \text { lembar) X (12 bulan) X ( } 25 \text { orang) } \\
=\text { Rp. 150.000.000 } \\
\text { Untuk bahan produksi (malam, pewarna, gas) per lembar rerata Rp. } \\
25.000 \text { per lembar. Dengan kapasitas produksi } 20 \text { lembar per bulan } \\
\text { per orang, maka perhitungan dilakukan sebagai berikut: harga } \\
\text { bahan produksi per lembar X kapasitas produksi X } 12 \text { bulan X } \\
\text { jumlah anggota. } \\
=(\text { Rp. } 25.000) \text { X ( } 20 \text { lembar }) X(12 \text { bulan }) X(25 \text { orang) } \\
=\text { Rp. 150.000.000 }\end{array}$ \\
\hline \multirow[t]{4}{*}{4} & \multicolumn{2}{|r|}{ - } \\
\hline & $\begin{array}{l}\text { Peningkatan jasa pengiriman } \\
\text { alat }\end{array}$ & $\begin{array}{l}\text { Alat pokok produksi batik berupa kompor dan kuali khusus seberat } \\
\text { retata } 8 \mathrm{~kg} \text {, dipesan dari luar kota. Dengan asumsi alat rusak dalam } \\
\text { setahun atau terjadi penambahan alat dalam setahun. Ongkos kirim } \\
\text { dari informasi web dari Jawa tengah ke Muara Enim sebesar Rp. } \\
51.000 \text { per kilogram. Kalkulasi dilakukan sebagai berikut; berat } \\
\text { barang X } 1 \text { tahun X ongkos kirim X jumlah anggota. } \\
=(8 \mathrm{~kg}) \text { X (1 tahun) X (Rp. } 51.000) X(25 \text { orang) } \\
=\text { Rp. 10.200.000 }\end{array}$ \\
\hline & $\begin{array}{l}\text { Peningkatan jasa pengiriman } \\
\text { kain }\end{array}$ & $\begin{array}{l}\text { Kapasitas produksi rerata } 20 \text { lembar per orang per bulan. Khusus } \\
\text { untuk kain dilihat dari harga pembelian per lembar seharga Rp. } \\
25.000 \text { per lembar, rerata harga sampai di Muara Enim Rp. } 40.000 \\
\text { per lembar, sehingga diasumsikan ongkos kirim Rp. } 15.000 \text { per } \\
\text { lembar. Perhtungan dilakukan sebagai berikut; kapasitas produksi } \\
\text { per orang per bulan X jumlah anggota X } 12 \text { bulan X ongkos kirim. } \\
=(20 \text { lembar) X ( } 25 \text { orang) X (12 bulan) X (Rp. } 15.000) \\
=\text { Rp. 90.000.000 }\end{array}$ \\
\hline & $\begin{array}{l}\text { Peningkatan jasa pengiriman } \\
\text { bahan produksi }\end{array}$ & $\begin{array}{l}\text { Dengan Kapasitas produksi rerata } 20 \text { lembar per orang per bulan, } \\
\text { diperlukan rerata bahan produksi (lilin, pewarna) seberat } 5 \mathrm{~kg} \text {. } \\
\text { Ongkos kirim dari Jawa Tengah sebesar Rp. } 51.000 \text { per kilogram. } \\
\text { Perhtungan dilakukan sebagai berikut; Berat bahan X jumlah } \\
\text { anggota X } 12 \text { bulan X ongkos kirim. } \\
=(5 \mathrm{~kg}) \mathrm{X}(25 \text { orang) X (12 bulan) X (Rp. } 51.000) \\
=\text { Rp. } \mathbf{7 6 . 5 0 0 . 0 0 0}\end{array}$ \\
\hline \multirow[t]{2}{*}{5} & \multicolumn{2}{|l|}{ Perbankan } \\
\hline & Peningkatan penabung & $\begin{array}{l}\text { Peningkatan pendapatan telah menumbuhkan tradisi menabung. } \\
\text { Berdasarkan hasil wawancara kemampuan minimal menabung per } \\
\text { orang rerata Rp. } 100.000 \text { per bulan. Untuk menghitung dampak } \\
\text { dilakukan sebagai berikut; Nilai kemampuan minimal menabung } \\
\text { per anggota X } 1 \text { tahun ( } 12 \text { bulan) X Jumlah pengrajin eksisting ( } 25\end{array}$ \\
\hline
\end{tabular}




\begin{tabular}{|c|c|c|}
\hline No. & Outcome & Hasil hitungan \\
\hline & & $\begin{array}{l}\text { orang). } \\
=(\text { Rp. } 100.000) \text { X (12 bulan) X (25 orang) } \\
=\text { Rp. 15.000.000 }\end{array}$ \\
\hline \multirow[t]{2}{*}{6} & \multicolumn{2}{|l|}{ Konsumen } \\
\hline & $\begin{array}{l}\text { Rasa bangga mempunyai } \\
\text { batik khas daerahnya sendiri }\end{array}$ & $\begin{array}{l}\text { Berdasarkan data BPS } 2018 \text { penduduk Muara Enim sebanyak } \\
68.711 \text { Jiwa. Diasumsikan 5\% penduduk membeli batik } 1 \text { kali } \\
\text { dalam setahun, dengan keuntungan jual per batik Rp. } 25.000 \text {. } \\
\text { Perhitungan dilakukan sebagai berikut: jumlah penduduk X \% } \\
\text { penduduk yang bertransaksi X } 1 \text { kali membeli per tahun X } \\
\text { keuntungan batik per buah. } \\
=(68.711 \text { orang) X (5\%) X (1 kali) X (Rp. } 25.000) \\
=\text { Rp. } 85.888 .750\end{array}$ \\
\hline
\end{tabular}

Sumber: Raharjo, S. T. (2019)

Dengan demikian, perhitungan SROI dari Program Sentra Industri Bukit Asam (SIBA) Batik Kujur adalah sebagai berikut:

Tabel 4

Perhitungan Input

\begin{tabular}{|c|l|r|c|}
\hline No. & \multicolumn{1}{|c|}{ Input } & \multicolumn{1}{|c|}{ Jumlah } & \multicolumn{1}{|c|}{ Total } \\
\hline 1 & Biaya instruktur (pengajar) & $82,500,000$ & \\
\hline 2 & Bantuan Bahan dan alat produksi & $48,217,500$ & \\
\hline 3 & Sarana pendukung pelatihan & $14,750,000$ & \\
\hline 4 & Uang saku peserta & $18,750,000$ & \\
\hline 5 & Pendampingan tahap I (produksi 1000 batik) & $163,250,000$ & \\
\hline 6 & Pendampingan tahap II & $70,750,000$ & \\
\hline \multicolumn{3}{|c|}{ Total } & $\mathbf{3 9 8 , 2 1 7 , 5 0 0}$ \\
\hline
\end{tabular}

Sumber: Raharjo, S. T. (2019)

Nilai input terbilang sebesar Rp. 398.217.500 (tiga ratus sembilan puluh delapan juta dua ratus tujuh belas ribu lima ratus rupiah).

Tabel 5

Perhitungan Output

\begin{tabular}{|c|c|c|c|}
\hline No. & Outcome & Hasil hitungan & Total \\
\hline \multirow[t]{6}{*}{1} & Pengrajin batik (sebagai personal) & & \\
\hline & $\begin{array}{l}\text { Peningkatan pendapatan (asumsi kapasitas produksi perbulan } \\
\text { per ogang: } 20 \text { lembar panjang } 3.5 \mathrm{~m} \text { ) }\end{array}$ & $450,000,000$ & \\
\hline & $\begin{array}{l}\text { Terhindar dari ketakutan ditagih hutang, Kemampuan } \\
\text { membayar utang }\end{array}$ & $450,000,000$ & \\
\hline & Pemenuhan kebutuhan harian dalam keluarga & $450,000,000$ & \\
\hline & Bisa berbagi dengan pihak lain (anggota keluarga, teman) & $30,000,000$ & \\
\hline & Bisa membiayai pendidikan anak & $150,000,000$ & \\
\hline \multirow[t]{2}{*}{2} & Masyarakat & & \\
\hline & $\begin{array}{l}\text { Kesediaan gotong rotong untuk membangun sentra batik } \\
\text { Kujur }\end{array}$ & $24,000,000$ & \\
\hline \multirow[t]{3}{*}{3} & Supplier alat dan bahan & & \\
\hline & Peningkatan penjualan alat produksi & $18,750,000$ & \\
\hline & Peningkatan penjualan bahan produksi & $300,000,000$ & \\
\hline \multirow[t]{4}{*}{4} & Ekspedisi & & \\
\hline & Peningkatan jasa pengiriman alat & $10,200,000$ & \\
\hline & Peningkatan jasa pengiriman kain & $90,000,000$ & \\
\hline & Peningkatan jasa pengiriman bahan produksi & $76,500,000$ & \\
\hline \multirow[t]{2}{*}{5} & Perbankan & & \\
\hline & Peningkatan penabung & $15,000,000$ & \\
\hline 6 & Konsumen & & \\
\hline
\end{tabular}

AdBispreneur : Jurnal Pemikiran dan Penelitian Administrasi Bisnis dan Kewirausahaan

Vol.5, No. 1, April 2020, DOI : https://doi.org/10.24198/adbispreneur.v5i1.26069, hal. 15-29 


\begin{tabular}{|c|c|r|c|}
\hline No. & Outcome & Hasil hitungan & \multicolumn{1}{c|}{ Total } \\
\hline & Rasa bangga mempunyai batik khas daerahnya sendiri & $85,888,750$ & \\
\hline \multicolumn{2}{|r|}{ Total } & $\mathbf{2 . 1 5 0 . 3 3 8 . 7 5 0}$ \\
\hline
\end{tabular}

Sumber: Raharjo, S. T. (2019)

Nilai outcome terbilang sebesar Rp. 2.150.338.750 (dua miliar seratus lima puluh juta tiga ratus tiga puluh delapan ribu tujuh ratus lima puluh rupiah).

Berdasarkan hasil perhitungan pada tabel 5, diperoleh hasil berikut:

Total input : $398,217,500$

Total outcome : 2.150 .338 .750

Dengan demikian, diperoleh rasio SROI (Total outcome/total input) sebagai berikut:

Rasio SROI

$2.150 .338 .750 / 398,217,500=5.39$

Dengan demikian, terindikasi dalam rasio SROI yang mencapai 1 : 5,39 di luar aspek-aspek kualitatif yang memiliki potensi dampak sosial, tetapi belum dapat di monetisasi. Rasio tersebut mengandung arti bahwa untuk setiap Rp. 1,yang diinvestasikan dalam Program SIBA Batik Kujur mampu menghasilkan dampak sosial sebesar Rp. 5,39.

\section{SIMPULAN}

Sebagai sebuah inisiasi baru dalam pendekatan pelaksanaan program CSR yang berangkat dari aspek budaya (sejarah) untuk menghasilkan aspek ekonomi, rasio SROI tersebut sudah cukup besar menghasilkan dampak sosial. Berdasarkan hasil penghitungan SROI, Program SIBA Batik Kujur terindikasi dalam rasio SROI yang mencapai $1: 5,39$ di luar aspek-aspek kualitatif yang memiliki potensi dampak sosial, tetapi belum dapat di monetisasi. Rasio tersebut mengandung arti bahwa untuk setiap Rp. 1,- yang diinvestasikan dalam Program SIBA Batik Kujur mampu menghasilkan dampak sosial sebesar Rp. 5,39. Tantangan berikutnya yang sangat penting untuk dilakukan oleh PTBA dan stakeholder lainnya adalah menjaga keberlanjutan dan kualitas dari Program SIBA Batik Kujur.

\section{DAFTAR PUSTAKA}

Badan Pusat Statistik. (2018). Kabupaten Muara Enim Dalam Angka 2018. Muara Enim: CV. Vika Jaya

Brouwers, J., Prins, E., Salverda, M. Herder, J, and Reynolds, E. (2010). Social Return on Investment: A Practical Guide for the
Development Cooperation Sector. Utrecht: Context, International Cooperation.

Cahya, B. T. (2014). Transformasi Konsep Corporate Social Responsibility (CSR). Iqtishadia. Vol. 7 No. 2. September 2014. Hlm. 203-222

Cektarif.com. (n.d.). Retrieved Oktober 8, 2019. from https://cektarif.com/ongkir-jneyogyakarta-ke-lawang-kidul-tj-enimmr-enim-1 kg-2019.html

Gray, R.H. (1990), Corporate Social Reporting by UK Companies: A Cross-Sectional and Longitudinal Study an Interim Report. Draft/Working Paper.

Gray, Rob, Reza Kouhy, and Simon Lavers, (1993). Social and Environmental Reporting by UK Companies: A Longitudinal Study. A Tale of Two Samples. The Construction of a Research Database and An Exploration of the Political Economy Thesis, Unpublished paper.

Guthrie, J. and L.D. Parker, (1990), "Corporate Social Disclosure Practice: A Comparative International Analysis", Advances in Public Interest Accounting, Vol. 3, pp. 159-175

Haniffa, R.M., dan T.E. Cooke, (2005), The Impact of Culture and Governance on Corporate Social Reporting, Journal of Accounting and Public Policy 24, pp. 391-430.

Jalal dan Kurniawan, F. (2013). Investasi Sosial: Perspektif CSR Strategis untuk Pengembangan Masyarakat oleh Perusahaan. Social Investment Indonesia: The Indonesian Social Investment Forum.

Kiroyan, Noke, (2006). Good Corporate Governance (GCG) dan Corporate Social Responsibility (CSR) Adakah Kaitan di Antara Keduanya?", Economics Business Accounting Review, Edisi III, SeptemberDesember 2006, Hal. 45-58. Pang, Y. H. 1982. Financial Reporting: Disclosures of Corporate Social Responsibility,raharjo 
The Chartered Accountant in Australia, July, 1982, pp. 32-34.

Purwohedi, Unggul. (2016). Social Return On Investment (SROI): sebuah teknik untuk mengukr manfaat/dampak dari sebuah program atau proyek. Yogyakarta: Leutikaprio

Raharjo, S. T. (2019). Laporan Social Return on Investment SIBA Batik Kujur Dusun Tanjung Enim. Kerjasama PT. Bukit Asam, Tbk. dengan Pusat Studi CSR, Kewirausahaan Sosial dan Pengembangan Masyarakat Universitas Padjadjaran.

Rusdin. (2016). Corporate Social Responsibility (CSR) Disclosure and the Implications of Earning Response Coefficient (ERC). Jurnal AdBispreneur. Vol. 1 No. 2 Agustus 2016. Hlm. 153-164

Santoso, M.B., Rivani, Ismanto, S.U., Mumajad, I. dan Mulyono, H. (2018). Penilaian Dampak Investasi Sosial Pelaksanaan CSR Menggunakan Metode Social Return on Investment (SROI)

Sayekti, Yosefa (2006), "Determinan Pengungkapan Informasi Corporate Social Responsibility (CSR) dalam Laporan Tahunan Perusahaan (Suatu Usulan Studi Empiris pada Perusahaan yang Terdaftar di Bursa Efek Jakarta), Tugas Mata Kuliah Seminar Doktoral Akuntansi Keuangan, Tidak Dipublikasikan, Program Pascasarjana Ilmu Akuntansi, FEUI.

Scholten, P., Nicholls, J. Olsen, S. and Galimidi, B. (2006). Social Return on Investment: a guide to SROI Analysis. Amstelveen: Lenthe Publishers 
30 AdBispreneur : Jurnal Pemikiran dan Penelitian Administrasi Bisnis dan Kewirausahaan Vol.5, No. 1, April 2020, DOI : https://doi.org/10.24198/adbispreneur.v5i1.26069, hal. 15-29 